九州大学学術情報リポジトリ

Kyushu University Institutional Repository

\title{
X-ray Powder Data for Kasoite
}

Shirozu, Haruo

Faculty of Science, Kyushu University

https://doi.org/10.5109/1543629

出版情報：九州大學理學部紀要：Series D, Geology. 16 (3)，pp.245-248，1965-11-20. Faculty of Science, Kyushu University バージョン：

権利関係 : 


\title{
X-ray Powder Data for Kasoite
}

\author{
By
}

\section{Haruo SHIRozU}

\section{Introduction}

Kasoite is a barium silicate $(\mathrm{BaO} 25.50 \%)$ described in 1936 as a feldspar with extreme deficiency in $\mathrm{SiO}_{2}$ from the Kaso mine, Japan by T. Yoshimura (1936), who concluded from the optical study that kasoite is a distinct mineral forming an isomorphous series with celsian. For its peculiar chemical composition, however, there may be possibilities that kasoite is not a feldspar or that the material is a mixture, e.g. perthite analogue consisting of feldspar and feldspathoid. Therefore, it is desirable to examine these points by means of X-ray, and Yoshimura suggested this work. This paper thus presents powder data for kasoite, which has been confirmed to be a feldspar.

\section{Experimental}

The kasoite sample examined is from the material of the original description. It forms a white compact veinlet with rhodonite, being lacking in single crystals. The powder pattern was taken with a Shimazu X-ray diffractometer, using filtered $\mathrm{Cu}$ radiation $(\lambda=1.5405 \AA)$. Instrumental settings were: scanning speed, $1 / 4^{\circ} 2 \theta$ per minute ; chart speed, $5 \mathrm{~mm}$ per minute; full scale, 500 counts per second; time constant, 5 seconds; receiving slit, $0.1 \mathrm{~mm}$. The readings of diffraction angles were corrected with an internal standard of silicon. The powder data obtained for kasoite are given in Table 1.

The powder pattern of kasoite is clearly of feldspar as compared in Fig. 1 with barium adularia ( $\mathrm{BaO}$ 3.36\%; Yoshimura, SHIROzU and KIMURA, 1954) and with celsian, which is artificial material obtained on heating synthetic hexacelsian ( $\mathrm{BaO}$ 41.68\%; Yoshiki and Matsumoto, 1951) at $1550^{\circ} \mathrm{C}$ for 5 hours. Fig. 1 may indicate that kasoite is as a whole intermediate between these two feldspars as to powder pattern, and is rather close to celsian. But relative intensities of some reflections are not always intermediate.

The powder data of Table 1 for kasoite were indexed assuming kasoite to be isomorphous with celsian, and the calculations of the qualified reffections between $4 \AA$ and $2.7 \AA$ yielded the following cell dimensions :

$$
\begin{aligned}
& a_{0}=8.608 \AA, \\
& b_{0}=13.035 \AA, \quad \beta=115^{\circ} 26.7^{\prime}, \\
& c_{0}=14.402 \AA .
\end{aligned}
$$

Manuscript received May 1, 1965. 
The calculated spacing values of Table 1 based on this cell are in good agreement with the observed values. The cell dimensions of celsian $(\mathrm{BaO} 35.8 \%)$ given by $\mathrm{R}$. $\mathrm{E}$. NEWNHAM and H. D. MEGAW (1960) are: $a_{0}=8.627 \AA, b_{0}=13.045 \AA, c_{0}=14.408 \AA \beta=115^{\circ} 13^{\prime}$. The dimensions of kasoite here obtained are slightly smaller than those of celsian. It may be explained primarily by the difference of their barium contents.

Thus the present results reveal that kasoite is a feldspar probably isomorphous with celsian, but afford no conclusion regarding the chemical complexity of kasoite and also regarding the probable discontinuity in the potassium-barium feldspar series.

\section{Acknowledgments}

I wish to acknowledge to Professor T. Yoshimura of Kyushu University for giving the opportunity to study kasoite and for his advice, and to Dr. B. YoshikI of Asahi Glass Company for supplying synthetic hexacelsian. Mr. M. OIsHI of Kurosaki Ceramic Company assisted in heating hexacelsian.

Table 1. X-ray powder diffraction data for Kasoite.

\begin{tabular}{|c|c|c|c|c|c|}
\hline$h k l$ & $d_{\text {obs. }}(\AA)$ & $\mathrm{I}$ & Qobs. & $Q_{\text {calc. }}$ & $d_{\text {calc. }}(\AA)$ \\
\hline $\left.\begin{array}{l}020 \\
002\end{array}\right\}$ & 6.52 & 4. & .0235 & $\begin{array}{l}.02354 \\
.02365\end{array}$ & $\begin{array}{l}6.517 \\
6.502\end{array}$ \\
\hline $11 \overline{2}$ & 5.87 & $\frac{1}{2}$ & .0290 & .02908 & 5.864 \\
\hline 022 & 4.61 & 3 & .0471 & .04719 & 4.603 \\
\hline $20 \overline{2}$ & 4.23 & $\frac{1}{2}$ & .0559 & .05585 & 4.231 \\
\hline 200 & 3.882 & 2 & .06636 & .06620 & 3.887 \\
\hline 130 & 3. 792 & 6 & .06954 & .06952 & 3.793 \\
\hline $13 \overline{2}$ & 3.624 & 3 & .07614 & .07617 & 3.623 \\
\hline $.22 \overline{2}$ & 3. 549 & 3. & .07939 & .07940 & 3.549 \\
\hline $11 \overline{1}$ & 3.471 & 7 & .08301 & .08304 & 3.470 \\
\hline 220 & 3. 338 & 10 & .08974 & .08975 & 3.338 \\
\hline $20 \bar{x}$ & 3. 282 & 3 & .09283 & .09280 & 3. 283 \\
\hline .004 & 3. 251 & 9 & .09461 & .09460 & 3.251 \\
\hline 132 & 3. 013 & 6 & .11015 & .11017 & 3.013 \\
\hline 042 & 2.913 & 4 & .11785 & .11782 & 2.913 \\
\hline $13 \overline{1}$ & 2.772 & 3 & .13014 & .13012 & 2.772 \\
\hline $\left.\begin{array}{l}222 \\
31 \overline{4}\end{array}\right\}$ & 2. 603 & 2 & .14758 & $\begin{array}{r}.14740 \\
.14744\end{array}$ & $\begin{array}{l}2.605 \\
2.604\end{array}$ \\
\hline $24 \overline{2}$ & 2.581 & 4 & .15011 & .15002 & 2.582 \\
\hline 114 & 2. 574 & 4 & .15093 & .15104 & 2.573 \\
\hline 310 & 2.539 & 2 & .15512 & .15484 & 2.541 \\
\hline $15 \overline{2}$ & 2.423 & 2 & .17033 & .17034 & 2.423 \\
\hline $33 \overline{2}$ & 2.391 & 1 & .17492 & .17458 & 2.393 \\
\hline $11 \overline{6}$ & 2.329 & 2 & .18435 & .18428 & 2.329 \\
\hline $33 \overline{1}$ & 2.266 & $\frac{1}{2}$ & .19474 & .19452 & 2.267 \\
\hline 134 & 2.246 & $\frac{1}{2}$ & .19824 & .19812 & 2.247 \\
\hline 152 & 2.213 & 1 & .20419 & .20434 & 2.212 \\
\hline 060 & 2. 174 & 4 & .21157 & .21187 & 2.173 \\
\hline
\end{tabular}




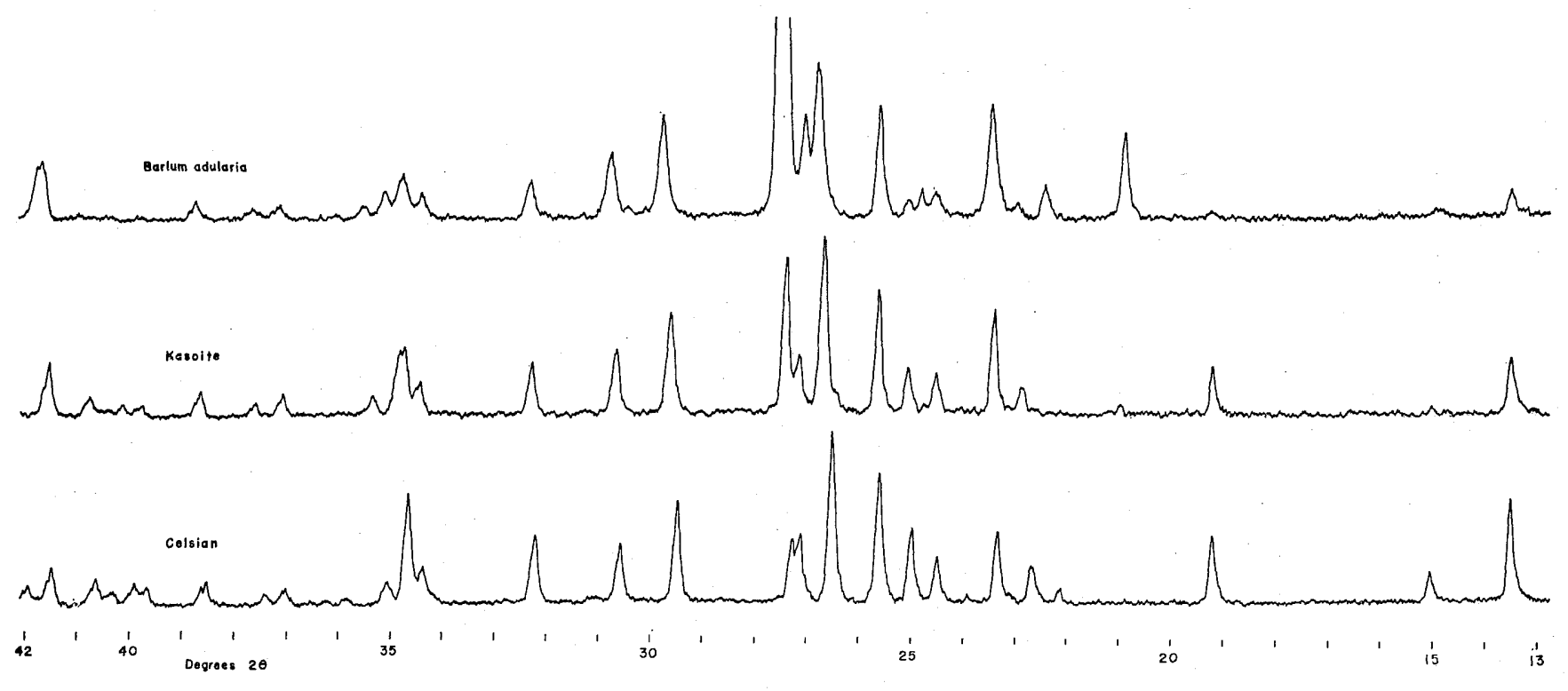

Fig. 1. X-ray powder diffraction patterns of barium feldspars. 


\section{References}

Newnham, R.E. and Megaw, H.D. (1960): The crystal structure of celsian. Acta Cryst., 13, 303-312.

Yoshiki, B. and Matsumoto, K. (1951): High-temperature modification of barium feldspar. Jour. Amer. Ceramic Soc., 34, 283-286.

Yoshimura, T. (1936): On barium feldspars from the Kaso mine, Tochigi Prefecture, Japan. Jour. Geol. Soc. Japan, 43, 877-910.

, Shirozu, H. and Kimura, M. (1954): Barium-adularia from the Isagosawa mine, Iwate Prefecture, Japan. Mem. Fac. Sci. Kyushu Univ., [D], 4, 163-165. 